Extra View

Iron toxicity

\title{
New conditions continue to emerge
}

\author{
Eugene D. Weinberg
}

Department of Biology and Program in Medical Sciences; Indiana University; Bloomington, IN USA

Abbreviations: ALS, amyotrophic lateral sclerosis; HCV, hepatitis C virus; HIV, human immunodeficiency virus; PAP, pulmonary alveolar proteinosis; PKAN, pantothenate kinase-associated neurodegeneration

Key words: aging muscle atrophy, iron, iron associated diseases, iron toxicity, pulmonary alveolar proteinosis, rosacea, viral replication

During the past half century, excessive/misplaced iron has been observed to be a risk factor for an increasing number and diversity of disease conditions. An extensive list of conditions and of the types of iron association were published in early 2008 . Within the subsequent year, four additional disorders have been recognized to be enhanced by iron: aging muscle atrophy, viral replication, rosacea and pulmonary alveolar proteinosis. This paper adds new data and emphasis on these disorders as entities associated with increased iron load and toxicity.

A review written early in 2008 contained an extensive list of diseases for which excessive and/or misplaced iron has been reported to be a causative or associated risk factor. ${ }^{1}$ The metal is toxic by catalyzing generation of hydroxyl radicals that intensify oxidative stress as well as by serving as a growth-essential nutrient for invading microbial and neoplasmic cells.

In the subsequent twelve months following submission of the manuscript, four additional conditions in which iron is toxic have been described: (a) intensification of aging muscle atrophy, ${ }^{2}$ (b) increased replication of human immunodeficiency virus (HIV) and hepatitis $\mathrm{C}$ virus $(\mathrm{HCV}),{ }^{3}$ (c) enhancement of rosacea, ${ }^{4}$ and (d) augmentation of pulmonary alveolar proteinosis (PAP). ${ }^{5}$ In this paper, the previously published tables of iron-related conditions and of the types of iron association are expanded to include these four conditions.

In the report on muscle atrophy, non-heme iron levels in gastrocnemius muscle in male rats increased by $233 \%$ between six and thirty months of age. ${ }^{2}$ Abundance of mRNA transferrin receptor- 1 decreased by $80 \%$. In related research in the same laboratory, non-heme iron and RNA oxidation increased significantly with age in quadriceps-derived subsarcolemma mitochondria. ${ }^{6}$ In a third

Correspondence to: Eugene D. Weinberg; Jordan Hall 142; Indiana University; Bloomington, IN 47405 USA; Tel.: +1.812.336.5556; Fax: +1.812.855.6705; Email: eweinber@indiana.edu

Submitted: 02/03/09; Revised: 02/09/09; Accepted: 02/12/09

Previously published online as an Oxidative Medicine and Cellular Longevity E-publication:

http://www.landesbioscience.com/journals/oximed/article/8162 related study, in rats between 29 and 37 months of age, non-heme iron in gastrocnemius muscle increased by $200 \%$ with an accompanying significant increase in oxidized $\mathrm{RNA}^{7}$ These changes were associated with evidence of sarcopenia; that is, decreased muscle mass and grip.

Although iron is not a component of viruses, infected host cells apparently need the metal to synthesize viral particles. During the past several decades, it has become manifest that one of the dangers of excessive iron is its ability to favor animal viral infections. ${ }^{8}$ The importance of iron in HIV infection has received particular attention. ${ }^{9}$ The multi-faceted molecular sites of action of iron in synthesis of HIV, as well as of HCV, are now being compiled. ${ }^{3}$ Of special interest are indications that viruses can manipulate iron homeostasis so as to ensure their replication in host cells.

Rosacea is a common chronic light-sensitive inflammatory skin disease. In this inquiry, peroxide and antioxidant potential of serum as well as of skin cell ferritin were assayed. ${ }^{4}$ Serum peroxide levels were higher and total anti-oxidant potential was lower in patients than in healthy controls $(\mathrm{p}<0.05)$. The number of ferritin positive cells was higher $(\mathrm{p}<0.001)$ in patient samples especially in those with severe disease. Ultraviolet irradiation of skin plus skin cell iron accelerated development of photo-sensitization, photoaging and skin cancer. ${ }^{10}$ It will be of interest to directly measure iron deposits in rosacea cells.

In the investigation on PAP, bronchoalveolar lavage samples of 20 patients were compared with those of 20 healthy volunteers. ${ }^{5}$ Concentrations of iron, transferrin, transferrin receptor, lactoferrin and ferritin were significantly elevated in PAP relative to healthy persons. In contrast, quantities of ascorbate, glutathione and urate were significantly depressed in PAP patients, indicative of antioxidant depletion. The results suggest an iron-catalyzed oxidative stress in the maintenance of PAP.

Similar alterations in pulmonary iron homeostasis have been observed in several other chronic lung diseases. ${ }^{11}$

The list of iron-associated diseases, whose compilation began 25 years ago, ${ }^{12}$ continues to grow (Tables 1 and 2). Recognition of the toxicity of iron is stimulating research efforts to develop iron chelator drugs that might be able to remove the metal from specific disease sites. ${ }^{13,14}$ 


\section{Table 1 Conditions for which excessive/misplaced iron can be a risk factor}

\begin{tabular}{|c|c|c|}
\hline Aging & Infectious & Ophthalmic \\
\hline muscle atrophy & $\begin{array}{l}\text { bacterial, fungal \& } \\
\text { protozoan infections }\end{array}$ & macular degeneration \\
\hline Cardiovascular & viral infections: HIV, HCV & Orthopedic \\
\hline atherosclerosis & & gout \\
\hline cardiomyopathy & Neurologic & hemophilic \\
\hline hypertension & ALS & synovitis \\
\hline ischemic stroke & Alzheimer & osteoarthritis \\
\hline \multirow[t]{2}{*}{ venous leg ulcer } & depression & osteoporosis \\
\hline & Friedreich ataxia & \\
\hline Dermal & Huntington & Otologic \\
\hline porphyria & multiple sclerosis & aminoglycoside \\
\hline cutanea tarda & Parkinson & toxicity \\
\hline \multirow[t]{2}{*}{ rosacea } & PKAN & \\
\hline & prion disease & Pediatric \& Neonatal \\
\hline Endocrine & & Down syndrome \\
\hline $\begin{array}{l}\text { diabetes } \\
\text { endometriosis }\end{array}$ & $\begin{array}{l}\text { Obstetric } \\
\text { neonatal }\end{array}$ & $\begin{array}{c}\text { epilepsy } \\
\text { sudden infant death }\end{array}$ \\
\hline $\begin{array}{l}\text { growth deficiency } \\
\text { hypogonadism }\end{array}$ & $\begin{array}{c}\text { hemochromatosis } \\
\text { pre-eclampsia }\end{array}$ & Pulmonary \\
\hline \multirow[t]{2}{*}{ hypothyroidism } & & alveolar proteinosis \\
\hline & Oncologic & cystic fibrosis \\
\hline Hepatic & breast & ozone lung injury \\
\hline cirrhosis & colorectal & pneumoconiosis \\
\hline steatohepatitis & esophageal & Renal \\
\hline \multirow[t]{3}{*}{ viral hepatitis } & hepatic & aminoglycoside \& \\
\hline & Kaposi sarcoma & vancomycin toxicity \\
\hline & $\begin{array}{c}\text { leukemia } \\
\text { lung }\end{array}$ & \\
\hline
\end{tabular}

Modifed from Table 3 (Weinberg et al.)'

\section{References}

1. Weinberg ED, Miklossy J. Iron withholding: A defense against disease. J Alz Dis 2008; 13:451-63.

2. Hofer T, Marzetti E, Xu J, Seo AY, Gulec S, Knutson MD, et al. Increased iron content and RNA oxidative damage in skeletal muscle with aging and disease atrophy. Exp Geront 2008; 43:563-70.

3. Drakesmith H, Prentice A. Viral infection and iron metabolism. Nat Rev Microbiol 2008; 6:541-55.

4. Tisma VS, Basta-Juzbasic A, Jaganjac M, Brcic L, Dobric I, Lipozencic J, et al. Oxidative stress and ferritin expresson in the skin of patients with rosacea. J Am Acad Dermatol 2009; 60:270-6.

5. Ghio AJ, Stoneheurner JG, Richards JH, Crissman KM, Roggli VL, Plantadosi CA, et al. Iron homeostasis and oxidative stress in idiopathic pulmonaryalveolar proteinosis. Respir Res 2008; 9:10.

6. Seo AY, Xu J, Servais S, Hofer T, Marzetti E, Wohlgemuth SE, et al. Mitochondial iron accumulation with age and functional consequences. Aging Cell 2008; 7:706-16.

7. Xu J, Knutson MD, Carter CS, Leeuwenburgh C. Iron accumulation with age, oxidative stress and functional decline. PLoS ONE 2008; 3:e2865.

8. Weinberg ED. Iron withholding: A defense against viral infections. BioMetals 1999; 9:393-9.

9. Weinberg GA, Boelaert JR, Weinberg ED. Iron and HIV infection. In Friis H, ed. Micronutrients and HIV Infection. CRC Press Boca Raton, FL 135-58.

10. Kitazawa M, Iwasaki K. Reduction of ultraviolet light-induced oxidative stress by amino acid chelators. Biochim BiophysActa 1999; 1473:400-8.

\section{Table 2 Association of iron with morbidity}

- Iron, by itself, has been observed to initiate the disease
cardiomyopathy
growth deficiency
hemophilic synovitis
hypogonadism
lung cancer
osteoporosis
pneumoconiosis

- Iron can be a cofactor in promoting the disease

Alzheimer

atherosclerosis

bacterial infections

diabetes

endometriosis

esophageal adenocarcinoma

fungal \& protozoan infections

gout

hepatoma

multiple sclerosis

osteoarthritis

oto- \& renal toxicity

ozone lung injury

pulmonary alveolar proteinosis

viral infections

- Iron deposits are observed in disease-associated tissue sites

basal ganglia in PKAN

hepatocytes in cirrhosis, steatohepatitis \& viral

hepatitis

mitochondria in Friedreich ataxia

pulmonary secretions in cystic fibrosis

retina in macular degeneration

skin cells in rosacea

skeletal muscle in aging

substantia nigra in Parkinson

thyroid in hypothyroidism

- Body iron loading is associated with above normal incidence of morbidity

ALS

breast cancer

colorectal cancer

depression

Down syndrome

epilepsy

hypertension

ischemic stroke

leukemia

pre-eclampsia

porphryia cutanea tarda

prion disease

sudden infant death syndrome

- Maternal antibodies can impair fetal iron metabolism

fetal or neonatal death in neonatal hemochromatosis

Modified from Table 4 (Weinberg et al.)' 
Iron toxicity

11. Ghio AJ. Disruption of iron homeostasis and lung disease. Biochim Biophys Acta (General Subjects) 2008; e-pub.

12. Weinberg ED. Iron withholding: A defense against infection and neoplasia. Physiol Rev 1984; 64:65-102.

13. Tam TF, Leung-Toung R, Li W, Wang Y, Karimian K, Spino M. Iron chelator research: Past, present, future. Curr Medicinal Chem 2003; 10:983-95.

14. Hider RC, Ma Y, Molina-Holgado F, Gaeta A, Roy S. Iron chelation as a potential therapy for neurodegenerative disease. Biochem Soc Trans 2008; 36:1304-8. 


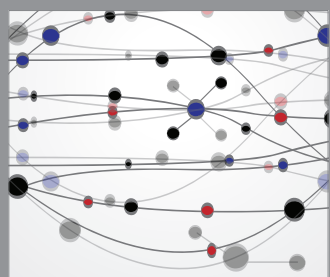

The Scientific World Journal
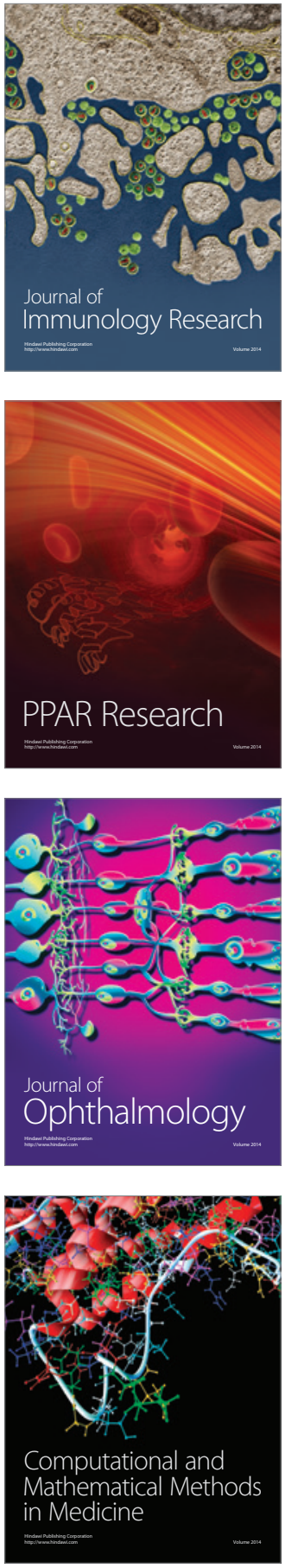

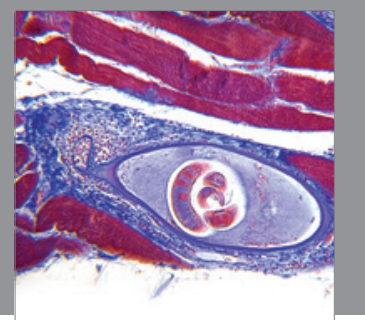

Gastroenterology

Research and Practice
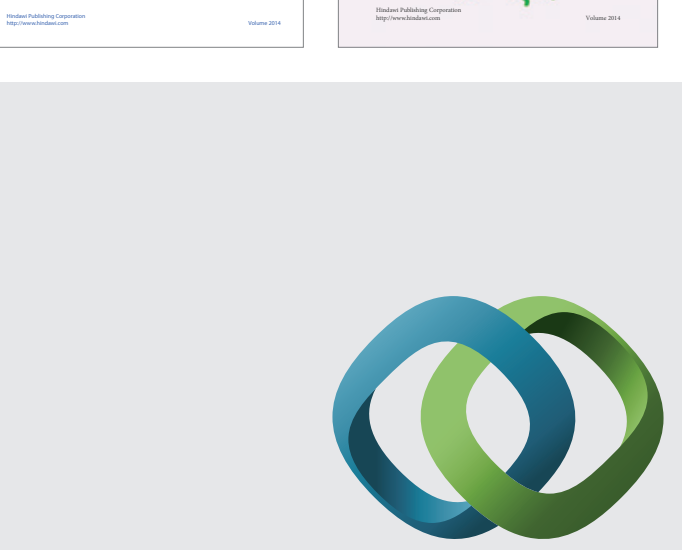

\section{Hindawi}

Submit your manuscripts at

http://www.hindawi.com
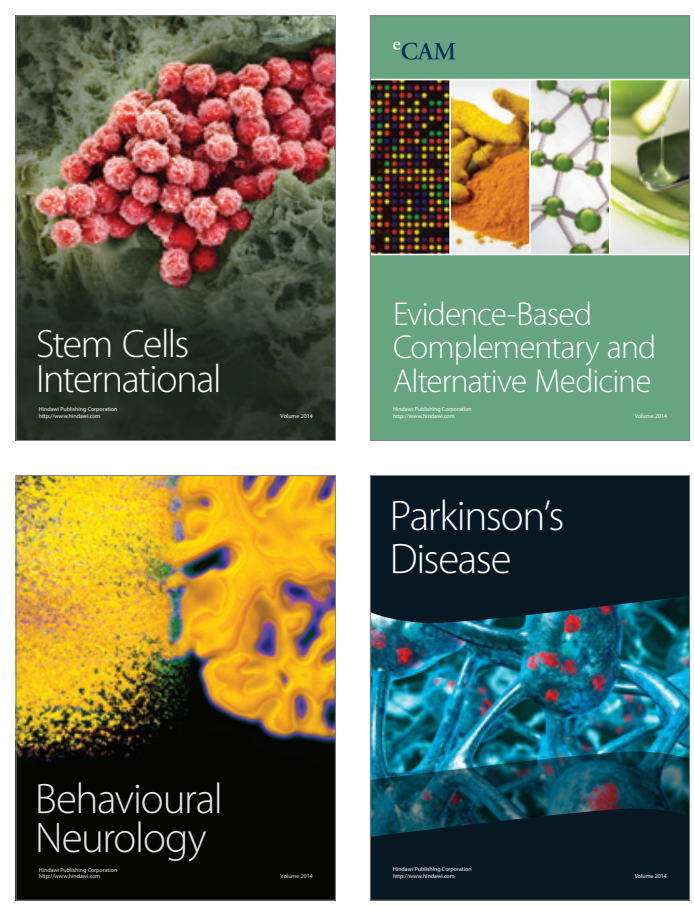

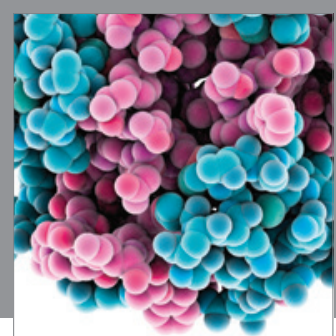

Journal of
Diabetes Research

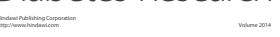

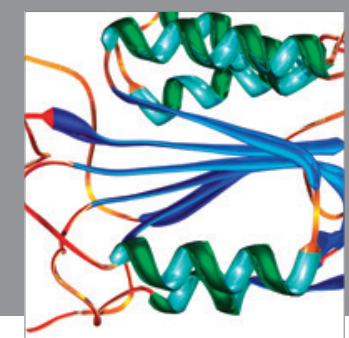

Disease Markers
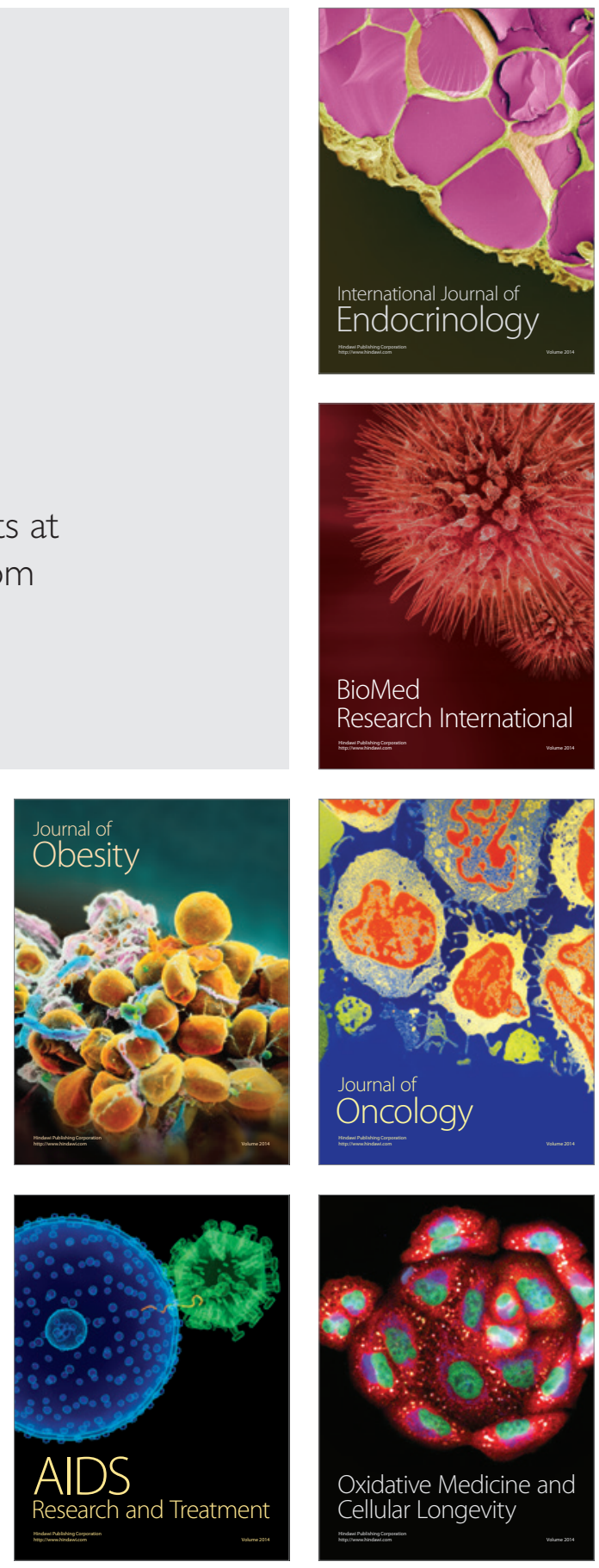